\title{
Can tissue elemental analysis be used to differentiate sarcoidosis and tuberculous lymphadenitis?
}

\author{
Ömer $\operatorname{ARAZ}^{1}(I D)$ \\ Aslı $\operatorname{ARAZ}^{2}$ (ID) \\ Elif YILMAZEL UÇAR ${ }^{\mathbf{1}}$ (ID) \\ Fatma AKDEMIR ${ }^{2}(I D)$ \\ Elif DEMIRCi ${ }^{3}$ (ID) \\ Yener AYDIN ${ }^{4}$ (ID) \\ Buğra KERGET $^{1}$ (ID) \\ Metin AKGÜN ${ }^{\mathbf{1}}$ (ID)
}

Cite this article as: Araz Ö, Araz A, Yllmazel Uçar E, Akdemir F, Demirci E, Aydin Y, et al. Can tissue elemental analysis be used to differentiate sarcoidosis and tuberculous lymphadenitis? Tuberk Toraks 2020;68(2):126-134.

\section{Yazışma Adresi (Address for Correspondence)}

Dr. Ömer ARAZ

Atatürk Üniversitesi Tıp Fakültesi,

Gögüs Hastalıkları Anabilim Dalı,

ERZURUM - TÜRKIYE

e-mail: dromeraraz@gmail.com

CCopyright 2020 by Tuberculosis and Thorax.

Available on-line at www.tuberktoraks.org.com
${ }^{1}$ Department of Chest Diseases, Faculty of Medicine, Atatürk University, Erzurum, Turkey

${ }^{1}$ Atatürk Üniversitesi Tıp Fakültesi, Gögüus Hastalıkları Anabilim Dalı, Erzurum, Türkiye

2 Department of Physics, Faculty of Science, Atatürk University, Erzurum, Turkey

${ }^{2}$ Atatürk Üniversitesi Fen Fakültesi, Fizik Bölümü, Erzurum, Türkiye

${ }^{3}$ Department of Medical Pathology, Faculty of Medicine, Atatürk University, Erzurum, Turkey

${ }^{3}$ Atatürk Üniversitesi Tıp Fakültesi, Tıbbi Patoloji Anabilim Dalı, Erzurum, Türkiye

${ }^{4}$ Department of Chest Surgery, Faculty of Medicine, Atatürk University, Erzurum, Turkey

${ }^{4}$ Atatürk Üniversitesi Tıp Fakültesi, Göğüs Cerrahisi Anabilim Dalı, Erzurum, Türkiye

\section{ABSTRACT}

Can tissue elemental analysis be used to differentiate sarcoidosis and tuberculous lymphadenitis?

Introduction: Sarcoidosis and tuberculous lymphadenitis are granulomatous inflammatory diseases. Differentiating lymph node involvement in these two diseases can be challenging. This study evaluated whether elemental analysis of tissue samples could facilitate the differentiation of these histopathologically and clinically similar diseases.

Materials and Methods: A total of 152 tissue samples were included: 57 caseating granulomatous inflammation, 58 non-caseating granulomatous inflammation, and 37 reactive lymph node specimens. The tissue samples were analyzed for calcium, magnesium, iron, copper, zinc, chrome, molybdenum, nickel and selenium with inductively coupled plasma-optical emission spectroscopy (ICP-OES).

Results: Comparison of element levels in the three groups revealed that caseating granulomatous inflammation had higher calcium content (662.6 \pm 4.6 ppm, $p<0.001)$ and lower iron content $(48.7 \pm 83$ ppm, $p<0.001)$ compared to non-caseating granulomatous inflammation. Compared to reactive lymph 
tissue, caseating granulomatous inflammation had higher calcium and lower iron and magnesium content while non-caseating granulomatous inflammation had higher levels of iron and lower magnesium; however, these differences were not statistically significant. In caseating granulomatous inflammation, a calcium cut-off value of 207 ppm yielded $85 \%$ specificity and $63 \%$ sensitivity. For iron, a cut-off value of $51 \mathrm{ppm}$ had $74 \%$ specificity and $58 \%$ sensitivity.

Conclusion: High calcium and low iron levels in lymph tissue may be suggestive of caseating granulomatous inflammation and tuberculosis. In cases where differentiating between sarcoidosis and tuberculous lymphadenitis is difficult, performing tissue elemental analysis may provide additional supportive evidence for differential diagnosis.

Key words: Sarcoidosis; tuberculosis; element; calcium; iron

\section{ÖZ}

\section{Sarkoidoz ve tüberküloz lenfadenit ayrımında doku element analizi kullanılabilir mi?}

Giriş: Sarkoidoz ve tüberküloz lenfadenit, granülomatöz inflamasyon oluşturan hastalıklardır. Bu iki hastalığın lenf bezi tutulumunun ayrımı bazı durumlarda güç olmaktadır. Bu çalışma, histopatolojik ve klinik olarak ayırıcı tanısında güçlük yaşayabildiğimiz bu hastaııklarda alınan doku örneklerinde çalışılan elementlerin hastalıkların ayrımına katkıda bulunup bulunmayacağını tespit etmek amacıyla yapılmıştır.

Materyal ve Metod: Çalışmaya 152 olgu alındı. Olguların 57'si kazeifiye granülomatöz inflamasyon, 58'i non-kazeifiye granülomatöz inflamasyon, 37'si ise reaktif lenf bezi doku örneklerinden oluşmaktaydı. Dokularda "inductively coupled plasma-optical emission spectroscopy (ICP-OES)" yöntemiyle kalsiyum, magnezyum, demir, bakır, çinko, krom, molibden, nikel ve selenyum elementlerinin analizi yapıldı.

Bulgular: Üç grup elde edilen elementlerin miktarları karşılaştırıldığında; kazeifiye granülomatöz inflamasyon ile non-kazeifiye granülomatöz inflamasyon karşılaştırıldığında kazeifiye granülomatöz inflamasyonda kalsiyum yüksek (662.6 \pm 4.6 ppm, p<0.001) ve demir miktarı düşük (48.7 \pm 83 ppm, p<0.001) idi. Kazeifiye granülomatöz inflamasyon ile reaktif lenf dokusu karşılaştırıldı̆̆ında kalsiyum yüksek, demir ve magnezyum düşük idi, non-kazeifiye granülomatöz inflamasyon ile reaktif lenf dokusu karşılaştırıldığında demir miktarı yüksek, magnezyum miktarı düşük idi ancak her iki karşılaştırmada istatistiksel olarak anlamlı fark yoktu. Kazeifiye granülomatöz inflamasyon da kalsiyumun 207 ppm "cutt-of" değeri için özgüllüğü \% 85, duyarlılı̆̆ı \%63 idi. Yine demir elementinin 51 ppm "Cutt-of" değeri için özgüllüğü \% 74, duyarlılığı \%58 idi.

Sonuç: Lenf bezi dokusunda kalsiyum yüksekliği ve demir düşüklüğ̈̈ kazeifiye granülomatöz inflamasyon, tüberküloz, lehine yorumlanabilir. Sarkoidoz ve tüberküloz lenf bezi tutulumunun ayrımında güçlük çekilen durumlarda, doku element analizinin yapılması hastalık ayrımında ek destekleyici bulgu verebilir.

Anahtar kelimeler: Sarkoidoz; tüberküloz; element; kalsiyum; demir

\section{INTRODUCTION}

Tuberculosis is a potentially fatal disease that is common worldwide. Tuberculosis can affect every system of the body, including the lymph system (1). Lymph node involvement may be mistaken for other diseases that can cause granulomatous reactions, especially sarcoidosis (2).

Although the etiology of tuberculosis is known, the etiology of sarcoidosis remains unclear. Various environmental, genetic, and host factors have been identified, but none are specific to sarcoidosis. It is believed to develop as the result of numerous potential factors (3). Elements have been implicated in the clinical course and etiology of both tuberculosis and sarcoidosis. Elements such as cobalt, copper, zinc, selenium, iron, and calcium are reported to play a role in the clinical course of tuberculosis; beryllium, zirconium, nickel, chromium, and synthetic mineral fibers have been implicated in the etiology of sarcoid- osis, but studies have been unable to demonstrate a definitive relationship (4-6).

In some cases, lymph node involvement in tuberculosis and sarcoidosis cannot be clearly distinguished based on tissue samples, which makes it difficult to initiate treatment. Our objective in the present study was to determine whether elemental analysis of tissue specimens acquired from patients with histopathologically ambiguous lymph node involvement could facilitate the differentiation of tuberculosis and sarcoidosis.

\section{MATERIALS and METHODS}

A total of 200 patients who admitted to our center were evaluated. In this retrospective study, 152 patients underwent mediastinoscopy with endobronchial ultrasound (EBUS) and lymph node biopsy. Fifty-seven caseating granulomatous inflammation, 58 non-caseating granulomatous inflammation, and 37 reactive lymphoid tissue samples were obtained 
from the patients during follow-up and treatment between 2012 and 2017. Patients with active involvement in the lung parenchyma, diagnosis of granulomatous inflammation, and those with indefinite diagnosis due to conflicting findings during follow-up were excluded.

\section{Tissue Sample Preparation}

Biopsy specimens were embedded in paraffin blocks and tissue samples were dried in an incubator at $80^{\circ} \mathrm{C}$ for 24 hours. The dried samples weighed approximately 0.5 g. Containers were cleaned and prepared by heating $5 \mathrm{~mL}$ of $\mathrm{HNO}_{3}$ in a microwave oven. The dried tissue samples were placed into the pressurized microwave containers and $3 \mathrm{~mL}$ of $30 \% \mathrm{H}_{2} \mathrm{O}_{2}$ and $2 \mathrm{~mL}$ of $65 \% \mathrm{HNO}_{3}$ were added sequentially (Figure 1 ).

After solubilizing the samples in the microwave oven, the containers were cooled at room tempera- ture for 30 minutes. The solutions were filtered through $125 \mathrm{~mm}$ diameter Whatman Grade 42 filter paper into $25 \mathrm{~mL}$ volumetric flasks. Distilled/deionized water was added to create a final volume of 25 $\mathrm{mL}$, which was then divided evenly into two $14 \mathrm{~mL}$ tubes.

Elemental analysis was performed on the solubilized tissue samples using an inductively coupled plasma-optical emission spectroscopy (ICP-OES) instrument (Optima 2100 DV ICP/OES, Perkin-Elmer, Shelton, CT, USA) (Figure 2).

\section{Inductively Coupled Plasma-Optical Emission Spectroscopy Analyzer}

The working principle of the device is that it uses high-temperature plasma to atomize the elements present in solubilized samples, then measures the light emissions of the elements to determine their

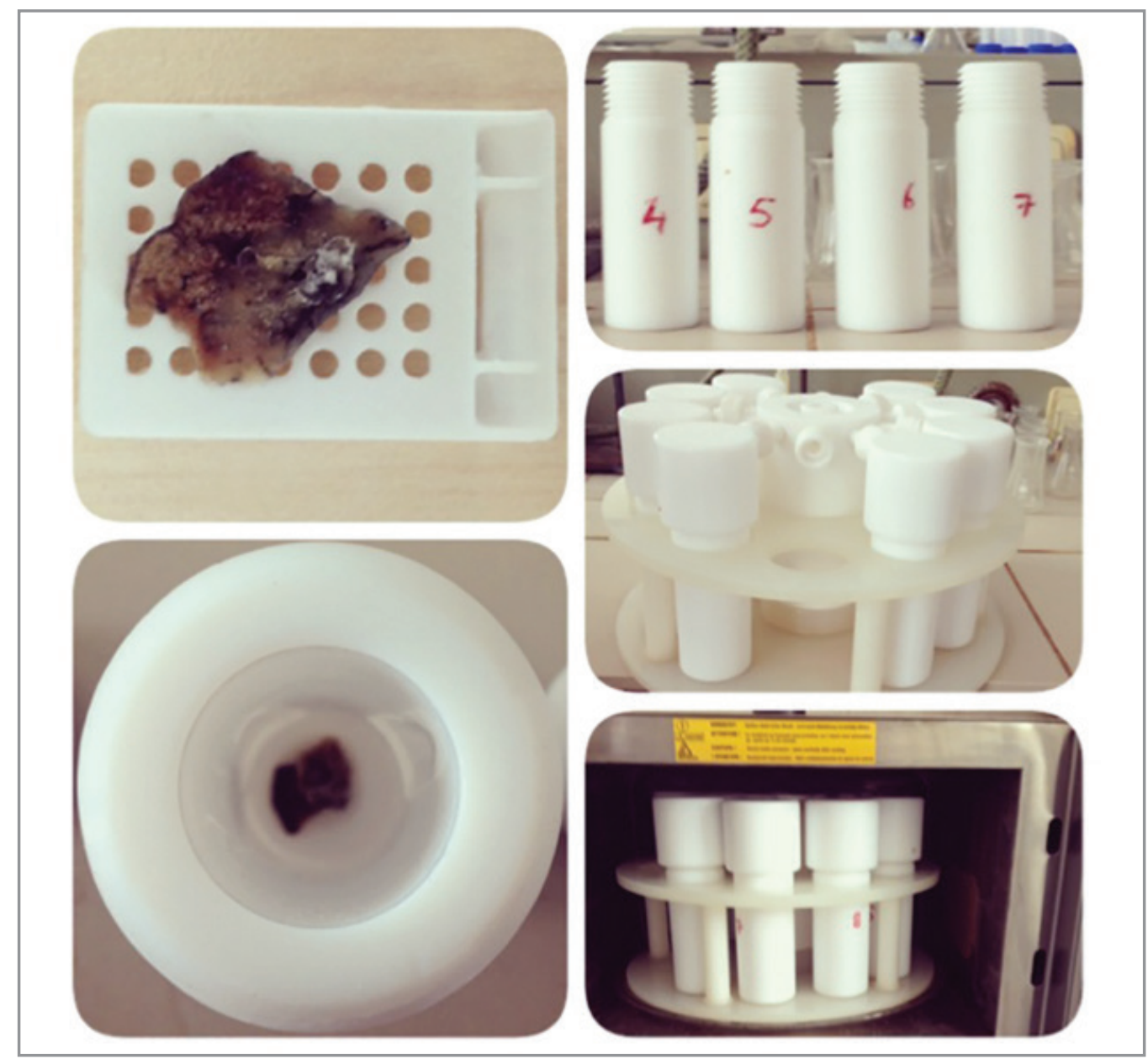

Figure 1. Acid is added to the tissue samples and placed in microwave oven. 


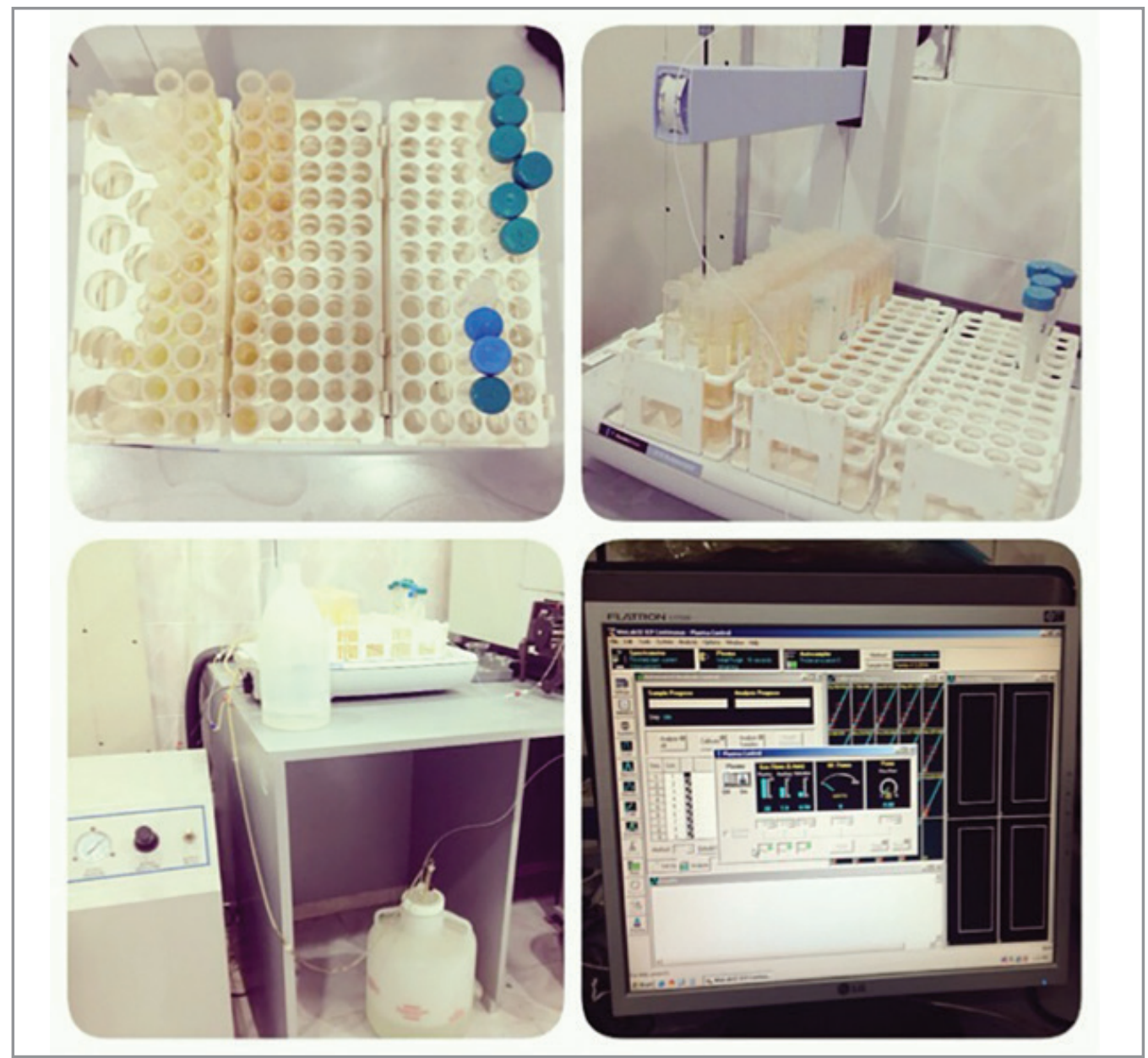

Figure 2. Sample analysis with the ICP-OES instrument.

concentrations in the solution. The advantages of ICP-OES are that it provides highly accurate, precise, and sensitive analytical results, it can assess low concentrations, and the device is easy to use (7).

\section{Elemental Analysis}

Nine elements were analyzed using the ICP-OES instrument: calcium $(\mathrm{Ca})$, magnesium $(\mathrm{Mg})$, iron $(\mathrm{Fe})$, copper $(\mathrm{Cu})$, zinc $(\mathrm{Zn})$, chromium $(\mathrm{Cr})$, molybdenum $(\mathrm{Mo})$, nickel $(\mathrm{Ni})$, and selenium (Se). Total element content was calculated after the analysis.

\section{Calculation of ICP-OES Results}

Concentrations expressed in $\mathrm{mg} / \mathrm{L}$ by the ICP-OES instrument were converted to $\mathrm{mg} / \mathrm{kg}$ [parts per million (ppm)] using the following formula:

$\mathrm{V} \times \mathrm{C} / \mathrm{m}=\mathrm{ppm}(\mathrm{mg} / \mathrm{kg})$
$\mathrm{V}=$ Sample volume $(\mathrm{mL}), \mathrm{C}=$ Sample concentration measured by the instrument $(\mathrm{mg} / \mathrm{L}), \mathrm{m}=$ Initial mass of the solid sample (g)

The study was designed in accordance with the ethical guidelines of the Declaration of Helsinki, and the study protocol was approved by the local ethics committee of the Atatürk University School of Medicine (B.30.2.ATA.0.01.00/129).

\section{Statistical Analysis}

The data were analyzed using SPSS version 18 (SPSS Inc., Chicago, IL, USA). Independent samples t-test was used to compare elemental content between groups. P values $<0.05$ were considered statistically significant. 


\section{RESULTS}

A total of 152 patients were included. Of these, 57 were male and 95 were female, with a mean age of $45.3 \pm 17.8$ (range 18-80 years). Twenty three patients were smokers and the mean pack-year value was $24.5 \pm 14.1$. The pathology specimens obtained from the patients were separated into three groups: 57 caseating granulomatous inflammation, 58 non-caseating granulomatous inflammation, and 37 reactive lymph node specimens. The demographic characteristics of the groups are shown in Table 1.

Groups were compared in terms of element content. Compared to non-caseating granulomatous inflammation, caseating granulomatous inflammation had significantly higher calcium content (662.6 \pm 4.6 ppm, $\mathrm{p}<0.001)$ and lower iron content $(48.7 \pm 83$ ppm, $p<0.001)$. Compared to reactive lymph tissue, caseating granulomatous inflammation showed higher calcium and lower iron and magnesium content, while non-caseating granulomatous inflammation had higher levels of iron and lower magnesium. However, these differences were not statistically sig- nificant. The element content of specimens in the groups is presented in Table 2.

In caseating granulomatous inflammation, calcium had $85 \%$ specificity and $63 \%$ sensitivity at a cut-off value of $207 \mathrm{ppm}$. For iron, a cut-off value of $51 \mathrm{ppm}$ had $74 \%$ specificity and $58 \%$ sensitivity. The receiver operating characteristic (ROC) curves for calcium and iron are shown in Figures 3 and 4.

\section{DISCUSSION}

The main finding of this study is that tissue from patients diagnosed histopathologically with caseating granulomatous lymphadenitis had higher calcium content and lower iron content when compared with specimens from patients with non-caseating granulomatous lymphadenitis and reactive lymph nodes.

In addition to amino acids, glucose, fatty acids, and vitamins, elements are necessary for cell replication and differentiation. Trace elements such as iron, zinc, copper, selenium, molybdenum, manganese, chromium, cobalt, and iodine are essential for health and

Table 1. Demographic characteristics of the groups

\begin{tabular}{|lccc|} 
& $\begin{array}{c}\text { Caseating granulomas } \\
(\mathbf{n = 5 7 )}\end{array}$ & $\begin{array}{c}\text { Non-caseating granulomas } \\
(\mathbf{n = 5 8})\end{array}$ & $\begin{array}{c}\text { Reactive lymphadenopathy } \\
(\mathbf{n = 3 7 )}\end{array}$ \\
\hline Age/year & $46.1 \pm 18.3$ & $39.4 \pm 15.9$ & $53.3 \pm 16.9$ \\
Gender (female/male) & $39 / 18$ & $42 / 16$ & $14 / 23$ \\
Smoking & 7 & 3 & 13 \\
\hline
\end{tabular}

\section{Table 2. Element levels in the tissue sample groups}

\begin{tabular}{|c|c|c|c|c|}
\hline $\begin{array}{l}\text { Elements } \\
(\mathrm{ppm})\end{array}$ & $\begin{array}{c}\text { Caseating } \\
\text { granulomas }\end{array}$ & $\begin{array}{c}\text { Non-caseating } \\
\text { granulomas }\end{array}$ & $\begin{array}{c}\text { Reactive } \\
\text { lymphadenopathy }\end{array}$ & p \\
\hline Calcium & $662.6 \pm 4.6$ & $205 \pm 1.1$ & $183 \pm 1.2$ & $<0.001^{*}$ \\
\hline Magnesium & $123.9 \pm 83$ & $107.4 \pm 75$ & $180.5 \pm 1.4$ & NS \\
\hline Iron & $48.7 \pm 30.4$ & $83 \pm 53.2$ & $81 \pm 97.1$ & $<0.001 *$ \\
\hline Copper & $23.4 \pm 21.9$ & $19 \pm 17$ & $22.8 \pm 23.6$ & NS \\
\hline Zinc & $1 \pm 0.83$ & $1 \pm 0.8$ & $0.99 \pm 1.2$ & NS \\
\hline Molybdenum & $6.2 \pm 8.6$ & $4.4 \pm 4.6$ & $4.1 \pm 5$ & NS \\
\hline Nickel & $5.2 \pm 4.1$ & $4.7 \pm 2.8$ & $4.2 \pm 2.9$ & NS \\
\hline Chromium & $1.9 \pm 2.0$ & $1.7 \pm 2$ & $1.6 \pm 1.6$ & NS \\
\hline Selenium & $26.3 \pm 19.2$ & $27.9 \pm 20.6$ & $25.6 \pm 18.9$ & NS \\
\hline
\end{tabular}




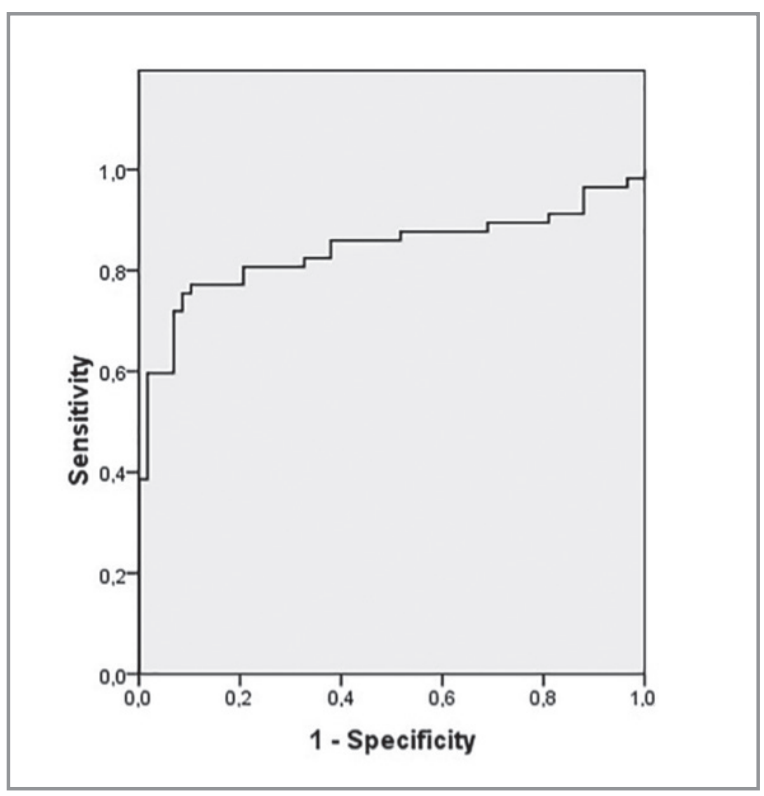

Figure 3. Receiver operating characteristic (ROC) curve of calcium in caseating granulomatous inflammation.



Figure 4. Receiver operating characteristic (ROC) curve of iron in caseating granulomatous inflammation.

should be consumed in the recommended quantities. Without these essential elements, organisms are unable to develop and reproduce normally. Essential elements are necessary for proper bone and blood composition, the maintenance of normal cellular functions, cognitive and physical development, muscle and nerve function, fluid and electrolyte balance, and the normal function of enzymes, hormones, and vitamins. These elements also have roles in other biological functions such as oxygen delivery and free radical deactivation (8).

Elements that have been associated with many diseases or disorders in humans are known to be influential in tuberculosis and sarcoidosis. Studies have shown that some tuberculosis patients have malnutrition. Secondary to malnutrition is insufficient intake of trace elements which are vital for development and defense, and which play a role in some diseases. Of these elements, copper, calcium, and iron are essential for immune system function. However, calcium and iron are also necessary for the vitality of Mycobacterium tuberculosis. There is also evidence regarding the effect of elements such as cobalt, zinc, and selenium on the disease (9-12).

Although the etiology of sarcoidosis has not been fully elucidated, it is known to be associated with environmental and occupational factors; risk is especially high among individuals who work in agriculture, use construction and gardening equipment, and are exposed to wood or organic particulate matter. Other occupational and environmental risk factors for sarcoidosis include exposure to metal dust and smoke, mold odor, microbial-rich environments, and smoking $(13,14)$. There are also a few case reports and small series in the field of cosmetics reporting sarcoid reactions associated with pigments containing metallic elements (15). Another study examining the relationship between the elements and sarcoidosis found that amounts of nickel, chromium, cobalt, zinc, copper, and selenium differed between sarcoidosis patients and controls (16).

Although it can be difficult to clinically and histopathologically distinguish between lymph system involvement of tuberculosis and sarcoidosis, there are well established relationships between these two diseases and elements. We conducted this study to evaluate whether elemental analysis could facilitate this differentiation, and our analysis of calcium, magnesium, iron, copper, zinc, chrome, molybdenum, nickel and selenium in patients with clinical/histopathologic diagnoses of tuberculosis, sarcoidosis, and reactive lymph node revealed that tuberculosis patients had significantly different levels of calcium and iron.

Calcium, which is one of the main metals found in the body, was detected in significantly greater amounts in caseating granulomatous tissue specimens. Its key role in the musculoskeletal and nervous 
systems is well known. At the same time, calcium plays an important role in the formation of the proinflammatory response. Calcium and vitamin D act in the modulation of inflammatory pathways and immune genes. In addition, calcium influences T cell receptors and is a critical component in oxidative stress pathways $(17,18)$. Previous studies have shown that calcium supplementation results in increased oxidative burst and reduces bacterial loads. Serum calcium level is related to vitamin $\mathrm{D}$, and vitamin $\mathrm{D}$ deficiency is associated with the incidence of tuberculosis, especially extrapulmonary manifestations $(19,20)$. While calcium plays an important role in host defense against $M$. tuberculosis, it also enables M. tuberculosis to survive within human macrophages by inhibiting sphingosine kinase $(21,22)$. We believe the high calcium content observed in the tuberculous lymph nodes compared to the non-caseating and reactive lymph nodes in our study is a result of the body's defense of taking calcium into the lymph tissue to use against $M$. tuberculosis.

In our study, calcium levels in non-caseating granulomatous tissue were lower than in caseating tissue One of the studies investigating the link between sarcoidosis and calcium showed that $3.7 \%$ of newly diagnosed patients had hypercalcemia and hypercalciuria (23). A study involving histopathological examination of lymph nodes in sarcoidosis revealed calcium oxalate crystals in the tissues (24). In sarcoidosis, increased calcium resulting from the enzyme activity of calcium 1-alpha hydroxylase released from alveolar macrophages and the resulting 1,25-dihydroxy vitamin D3 production does not seem to have a significant effect on calcium in the lymphoid cells due to its low levels in non-caseating inflammation tissue.

Iron is an essential element for the development of nearly every body system. It is found in the body mostly in complex binding proteins such as transferrin, lactoferrin, and ferritin (25). This element is necessary both for parasites and host body cells (26). Iron is particularly essential for T cell function, immunoglobulin secretion, interleukin-6 secretion, and neutrophil activity (27). Similarly, iron is an indispensable element in $M$. tuberculosis development. Increased dietary iron intake has been shown to correlate with tuberculosis morbidity and mortality. The success of $M$. tuberculosis is related to its ability to excrete toxic metals and proliferate within the host (28-30). Iron is a component of superoxide dismutases, which turn superoxide (a strong antibacteri- al agent) into hydrogen peroxide (a weak agent). $M$. tuberculosis then converts hydrogen peroxide into water (31). Decreased iron levels are seen in patients with tuberculosis before initiation of treatment and are associated with anemia in active TB (32). Iron level increases about four months after starting antituberculosis therapy (33). In a clinical trial association between dietary iron and tubercolosis was evaluated and increased risk of potent infection and mortality among HIV-tuberculosis infected patients was observed (34). We believe that the relatively low iron content in the lymph nodes of patients with tuberculosis in our study was attributable to the amount of iron used by the M. tuberculosis in the tissues.

Although there are many studies in the literature regarding the relationship between tuberculosis and iron, data concerning the relationship between sarcoidosis and iron are limited. In elemental analysis of tissue samples from two patients with suspected sarcoidosis, substantial amounts of iron were detected in one of them (35). In another case, electron microscopy analysis of paraffin-embedded tissue revealed the presence of metal particles (iron oxide, titanium oxide, aluminum oxide, and steel) in the sample (36). In many sarcoidosis patients, inclusion bodies are found in the giant cells within granulomas. Most of these giant cells contain crystalline oxalate, which chemically coordinates the iron on its surface. If this iron is not fully coordinated and remains available for redox cycling, oxalate may contribute to the formation of granuloma in the lung. Granuloma formation and calcium oxalate deposition in the lungs are associated with iron-mediated oxidative stress in sarcoidosis (37). The higher iron content in the tissues of sarcoidosis patients compared to the other tissues suggests that iron may play a role in the etiology of sarcoidosis through granuloma formation.

There is a paucity of data in the literature pertaining to elemental analysis of tissue samples from caseating and non-caseating granulomatous inflammation and to the best of our knowledge, no comparative studies have been performed to date. For this reason, our study is a first in this area and may help solve this dilemma. The main limitation of our study is the lack of M. tuberculosis culture in our patients. This was due to the fact that we retrospectively analyzed lymph node tissue specimens, and M. tuberculosis culture was not done in some cases during initial diagnosis of tuberculosis. 


\section{CONCLUSION}

Our results in this study indicate that findings of high calcium and low iron levels in lymph tissue, especially caseating granulomatous inflammation, may be suggestive of tuberculosis. In cases where differentiating between lymph node involvement in sarcoidosis and tuberculosis is difficult, performing tissue elemental analysis may facilitate differential diagnosis. If our findings are supported by larger studies, this method may be applied in clinical practice.

\section{CONFLICT of INTEREST}

The authors declare that there are no conflicts of interest.

\section{AUTHORSHIP CONTRIBUTIONS}

Concept/Design: ÖA, AA

Analysis/Interpretation: AA, FA, BK

Data Acquisition: YA, ED

Writting: EYU, ÖA

Critical Revision: MA

Final Approval: MA

\section{REFERENCES}

1. World Health Organization. Global Tuberculosis Report 2019. Available online: http://www.who.int/tb/publications/global_report/en/ (accessed on 17 October 2019).

2. Karpathiou G, Batistatou A, Boglou P, Stefanou D, Froudarakis ME. Necrotizing sarcoid granulomatosis: a distinctive form of pulmonary granulomatous disease. Clin Respir J 2018;12(4):1313-9.

3. Chen ES, Moller DR. Etiology of sarcoidosis. Clin Chest Med 2008;29(3):365-77.

4. Burtis CA, Ashwood ER, Bruns DE. Tietz Textbook of Clinical Chemistry and Molecular Diagnostics. Elsevier Health Sciences: St Louis, MO, USA, 2012.

5. Hood MI, Skaar EP. Nutritional immunity: transition metals at the pathogen-host interface. Nat Rev Microbiol 2012;10:525-37.

6. Lazarus A. Sarcoidosis: epidemiology, etiology, pathogenesis, and genetics. Dis Mon 2009;55:649-60.

7. Carpenter R. The analysis of some evidential materials by inductively coupled plasma-optical emission spectrometry. Forensic Science International 1985;27:157-63.

8. Patriarca M, Menditto A, Di Felice G. Recent developments in trace element analysis in the prevention, diagnosis, and treatment of diseases. Microchemical Journal 1998;59:194-202.
9. Araz O, Araz A, Yılmazel UE, Demirci E, Aydın Y, Akgün M. The effect of surgical specimen-derived phosphorus and lead concentrations in non-small cell lung cancer patients on disease course. Tuberk Toraks 2018;66(4):334-9.

10. Kirenga BJ, Ssengooba W, Muwonge C, et al. Tuberculosis risk factors among tuberculosis patients in Kampala, Uganda: implications for tuberculosis control. BMC Public Health 2015;15:13.

11. Choi R, Kim HT, Lim Y, et al. Serum concentrations of trace elements in patients with tuberculosis and its association with treatment outcome. Nutrients 2015;7(7):5969-81.

12. Sargazi A, Gharebagh RA, Sargazi A, Aali H, Oskoee HO, Sepehri Z. Role of essential trace elements in tuberculosis infection: a review article. Indian J Tuberc 2017;64(4):24651.

13. Moller DR, Rybicki BA, Hamzeh NY, et al. Genetic, immunologic, and environmental basis of sarcoidosis. Ann Am Thorac Soc 2017;14(Suppl 6):S429-S436.

14. Barnard J, et al. ACCESS Research Group 2005 Job and industry classifications associated with sarcoidosis in A Case-Control Etiologic Study of Sarcoidosis (ACCESS) I Occup Environ Med 2005;47(3):226-34.

15. Antanovich DD, Callen JP. Development of sarcoidosis in cosmetic tattoos. Arch Dermatol 2005;141(7):869-72.

16. Corradi M, Acampa O, Goldoni M, et al. Metallic elements in exhaled breath condensate of patients with interstitial lung diseases. J Breath Res 2009;3(4):046003.

17. Noble A, Truman JP, Vyas B, Vukmanovic-Stejic M, Hirst WI, Kemeny DM. The balance of protein kinase $C$ and calcium signaling directs $T$ cell subset development. I Immunol 2000;164(4):1807-13.

18. Ermak G, Davies KJ. Calcium and oxidative stress: from cell signaling to cell death. Mol Immunol 2002;38(10):71321.

19. Rook GA. The role of vitamin $D$ in tuberculosis. Am Rev Respir Dis 1988;138(4):768-70.

20. Davies P. A possible link between vitamin $D$ deficiency and impaired host defence to Mycobacterium tuberculosis. Tubercle 1985;66(4):301-6.

21. Malik ZA, Thompson CR, Hashimi S, Porter B, lyer SS, Kusner DJ. Cutting edge: Mycobacterium tuberculosis blocks Ca2+ signaling and phagosome maturation in human macrophages via specific inhibition of sphingosine kinase. I Immunol 2003;170(6):2811-5.

22. Gupta S, Salam N, Srivastava V, et al. Voltage gated calcium channels negatively regulate protective immunity to Mycobacterium tuberculosis. PLoS ONE 2009;4(4):e5305.

23. Baughman RP, Teirstein AS, Judson MA, et al. A CaseControl Etiologic Study of Sarcoidosis (ACCESS) research group. Clinical characteristics of patients in a case control study of sarcoidosis. Am J Respir Crit Care Med 2001;164(2):1885-9. 
24. Ma Y, Gal A, Koss MN. The pathology of pulmonary sarcoidosis: Update. Semin Diagn Pathol 2007;24(3):15061.

25. Weinberg ED. Iron loading and disease surveillance. Emerg Infect Dis 1999;5(3):346.

26. Litwin CM, Calderwood $S$. Role of iron in regulation of virulence genes. Clin Microbiol Rev 1993;6(2):137-49.

27. Li J, He K, Liu P, Xu LX. Iron participated in breast cancer chemoresistance by reinforcing IL-6 paracrine loop. Biochem Biophys Res Commun 2016;475(2):154-60.

28. Gangaidzo IT, Moyo VM, Mvundura E, et al. Association of pulmonary tuberculosis with increased dietary iron. I Infect Dis 2001;184(7):936-9.

29. De Voss JJ, Rutter K, Schroeder BG, Su H, Zhu Y, Barry CE. The salicylate-derived mycobactin siderophores of Mycobacterium tuberculosis are essential for growth in macrophages. Proc Natl Acad Sci USA 2000;97(3):12527.

30. Ratledge C, Dover LG. Iron metabolism in pathogenic bacteria. Annu Rev Microbiol 2000;54:881-941.

31. Yuniastuti A. The role and characteristic of antioxidant for redox homeostasis control system in Mycobacterium tuberculosis. Int Res J Microbiol 2012;3:416-22.
32. Karyadi E, Schultink W, Nelwan RH, et al. Poor micronutrient status of active pulmonary tuberculosis patients in Indonesia. I Nutr 2000;130(12):2953-8.

33. Edem V, Ige O, Arinola O. Plasma vitamins and essential trace elements in newly diagnosed pulmonary tuberculosis patients and at different durations of anti-tuberculosis chemotherapy. Egypt J Chest Dis Tuberc 2015;64(1):6759.

34. Gangaidzo IT, Moyo VM, Mvundura E, et al. Association of pulmonary tuberculosis with increased dietary iron. I Infect Dis 2001;184(7):936-9.

35. Tomioka H, Kaneda T, Katsuyama E, Kitaichi M, Moriyama $H$, Suzuki E. Elemental analysis of occupational granulomatous lung disease by electron probe microanalyzer with wavelength dispersive spectrometer: Two case reports. Respir Med Case Rep 2016;18:66-72.

36. Catinon $M$, Chemarin $C$, Roux $E$, Cavalin $C$, Rosental PA, Thivolet-Bejui $F$, et al. Polishing surgical metal pieces, granulomatosis and mineralogical analysis. Sarcoidosis Vasc Diffuse Lung Dis 2016;33(2):166-70.

37. Ghio Al, Roggli VL, Kennedy TP, Piantadosi CA. Calcium oxalate and iron accumulation in sarcoidosis. Sarcoidosis Vasc Diffuse Lung Dis 2000;17(2):140-50. 